\title{
Synthesis and biological evaluation of retinoid-chalcones as inhibitors of colon cancer cell growth
}

\author{
Cassia S. Mizuno ${ }^{1,}{ }^{,}$, Shiby Paul ${ }^{2}$, Nanjoo Suh${ }^{2}$, and Agnes M. Rimando ${ }^{1}$ \\ 1 U.S. Department of Agriculture, Agricultural Research Service, Natural Products Utilization \\ Research Unit, University, MS 38677 \\ 2Department of Chemical Biology, Ernest Mario School of Pharmacy, Rutgers, The State \\ University of New Jersey, 164 Frelinghuysen Road, Piscataway, NJ 08854
}

\begin{abstract}
Based on the observed anticancer activity of chalcones and retinoids, a novel class of retinoidchalcone hybrids was designed and synthesized. As part of our ongoing studies to discover natural product based anticancer compounds, the retinoid-chalcone hybrids were tested against the colon cancer cell line HT-29. Retinoid like moiety was introduced through Friedel-Crafts alkylation of toluene. Among the synthesized compounds, the cyano derivative (E)-3-(3-oxo-3-(3,5,5,8,8pentamethyl-5,6,7,8-tetrahydronaphthalen-2-yl)prop-1-enyl)benzonitrile 8 showed submicromolar inhibitory activity with an $\mathrm{IC}_{50}$ of $0.66 \mu \mathrm{M}$.
\end{abstract}

\section{Keywords}

Chalcones; retinoids; HT-29 cells; colon cancer

\begin{abstract}
Chalcones are secondary metabolite precursors of flavonoids and isoflavonoids, which are commonly found in edible plants. The presence of flavonoids in fruits and vegetables has been related to the health benefits of this food group. A good safety profile, possibility of oral administration, 1 and easy synthesis are the major factors contributing to the increasing interest in exploring the pharmacological activities of chalcones. In addition, chalcones have been reported to exhibit several biological activities, including antitumor,2, 3 antiinflammatory, 4,5 immunomodulatory, 6 antibacterial, 7 antimalarial, 8 antileishmanial, 9 trypanocidal 10 and nitric oxide inhibitory activity. 11 Chalcones comprise one of the main classes of natural small molecules with very promising anticancer activity, related to their ability to inhibit tubulin polymerization.12 Several groups have focused on the antitumor activity of this class of compounds. There are a number of reports on the activity of chalcones against several cell lines including prostate 13 and breast cancer14 in low nanomolar concentration.
\end{abstract}

Retinoids are derivatives of vitamin A. Investigation of the therapeutic use of this class of compounds dates back to the 1970s.15 However, toxicity has limited the clinical use of retinoids. This toxicity is related to the high hydrophobic nature of the compounds, and is

\footnotetext{
*Corresponding Author: Cassia S. Mizuno, Ph.D., P.O. Box 8048, University, MS 38677, Phone: 662-915-1046; Fax: 662-915-1035 cmizuno@olemiss.edu.

Publisher's Disclaimer: This is a PDF file of an unedited manuscript that has been accepted for publication. As a service to our customers we are providing this early version of the manuscript. The manuscript will undergo copyediting, typesetting, and review of the resulting proof before it is published in its final citable form. Please note that during the production process errors may be discovered which could affect the content, and all legal disclaimers that apply to the journal pertain.
} 
usually presented as an over-expression of the physiological functions of the retinoids.16 Retinoids are regulators of important biological events, including cell differentiation and proliferation; 12 thus, they have been developed as anticancer agents. One example of a drug belonging to this class is targretin, a synthetic retinoid available in the market for treatment of cutaneous T-cell lymphoma.17

In an attempt to improve anticancer activity, a retinoid moiety was introduced into chalcone template, generating a class of retinoid-chalcone hybrids. Similar work has been done by Kagechika et al. in which the authors synthesized hybrid chalcones with strong ability to induce differentiation of HL-60 cells into mature granulocytes.18 In another study, Romagnoli et al. have reported increased antiproliferative activity of hybrid $\alpha$ bromoacryloylamido chalcones compared to the corresponding amino chalcones. 2

In this work, a series of retinoid-chalcone hybrids (Fig. 1) was synthesized. The tetramethylcyclohexane group on ring A was fixed, and diversity was created by introducing different substituents on ring $\mathrm{B}$. The rationale for fixing ring A was based on the previously mentioned work of Kagechika et al.,18 where the authors reported the synthesis of chalcones containing a tetramethylcyclohexane group in ring A with stronger activity than retinoic acid.

All molecules were tested for inhibition of growth of HT-29 cells. The HT-29 cell line was chosen as a representative human colon cancer cell line; these colon carcinoma cells are $A p c$-null and contain wild-type $\beta$-catenin protein, and they respond well to compounds to induce E-cadherin protein levels and decrease c-Myc and cyclin D1.19-22

Synthesis of retinoid-chalcone hybrids is shown in Scheme 1. Toluene 1 underwent FriedelCrafts alkylation23 using 2,5-dichloro-2,5-dimethylhexane and aluminum chloride in dichloromethane to afford tetrahydronaphthalene $\mathbf{2}$. Friedel-Crafts acylation 23 of $\mathbf{2}$ in the presence of acetyl chloride gave $\mathbf{3}$. Coupling of acetophenone $\mathbf{3}$ with different aldehydes was accomplished using $\mathrm{NaOH}$ in ethanol and afforded the chalcone-retinoid hybrids. Reduction of the nitro derivative $\mathbf{2 0}$ using sodium dithionite 24 gave amino compound $\mathbf{1 5}$. Prenylated chalcones 16 and 17 were synthesized from $O$-alkylation of chalcones-bearing hydroxyl groups using potassium carbonate according to procedures by Johnston et al.25

The retinoid-chalcone derivatives were tested for their growth inhibitory effect on HT-29 cell lines.21 The cells were incubated with varying concentrations of the test compounds for 3 days at $37^{\circ} \mathrm{C}$. The results of the assay are shown in Table 1 . Structure activity relationship studies were performed on the B ring of the retinoid-chalcone hybrids. Groups such as methoxy, halogens, hydroxyl, amino and tetrazole were introduced on the $3^{\prime}, 4^{\prime}$, and $5^{\prime}$ positions to generate diversity. Results from the biological assay showed that, in general, electron withdrawing groups at the meta position of the benzene ring are better for activity. Thus, the best compound was the cyano derivative 8 with an $\mathrm{IC}_{50}=0.66 \mu \mathrm{M}$. Changes in the substitution patterns have different effects on the inhibitory activity depending on the functional group on B-ring. Shifting the cyano group from the meta $(\mathbf{8})$ to para $(\mathbf{6})$ position decreased activity almost three fold, while the same change with the nitro containing hybrids (20 and 12) did not affect activity.

Electron donating groups at the meta position were not as effective as the electronwithdrawing groups. Compound $\mathbf{1 4}$ with a hydroxyl group was four fold less active than cyano derivative 8. Bulky groups at the para position are less favored than at the meta position. This is supported by comparing the activity of meta substituted compound $\mathbf{1 7}$ $\left(\mathrm{IC}_{50}=3.73 \mu \mathrm{M}\right)$ and para substituted compound $16\left(\mathrm{IC}_{50}=13.33 \mu \mathrm{M}\right)$. Furthermore, compound 21 with a tetrazole group was the least active. With the exception of compound 
12, the para substituted compounds showed the lowest inhibitory activity, indicating that substitution at that position is not well tolerated.

When the activity of compounds $\mathbf{5}$ and $\mathbf{6}$ was compared, it was noticeable that, for this particular pair of compounds, the introduction of the retinoid moiety improved the activity. However, having the retinoid group alone does not guarantee activity; the activity varied depending upon the substituents in the benzene ring, as evident from the $\mathrm{IC}_{50}$ values.

For disubstituted compounds, a 3,5- substitution appeared to be better than a 3,4substitution. Thus, 3,5-dimethoxy-substituted $\mathbf{1 8}$ showed better activity than 3,4-dimethoxy derivative 19 and 3,4-dichloro derivative 22. Interestingly, however, 3,4-substituted compound 23 had better activity than either of the meta-monosubstituted compounds 14 and 9. It appeared that, together as substituents in the same molecule, the hydroxy and methoxy groups improve activity. Unsubstituted compound $\mathbf{7}$ showed moderate inhibitory activity, which was better than most of the para substituted compounds.

In this work we described the synthesis and biological evaluation of a group of retinoidchalcone hybrids. The compounds were tested against colon cancer cell lines HT-29 and the most inhibitory compound $\mathbf{8}$ showed activity in the low micromolar range. In general, from SAR point of view, the meta-substituted compounds showed better activity than parasubstituted compounds.

\section{Supplementary Material}

Refer to Web version on PubMed Central for supplementary material.

\section{Acknowledgments}

This research was supported in part by NIEHS P30ES005022 and the Trustees Research Fellowship Program at Rutgers, The State University of New Jersey. We would like to thank Mrs. Juanita Boutin for proofreading this manuscript.

\section{References and notes}

1. Vanhoecke BW, Delporte F, Van Braeckel E, Heyerick A, Depypere HT, Nuytinck M, De Keukeleire D, Bracke ME. In Vivo. 2005; 19:103. [PubMed: 15796161]

2. Romagnoli R, Baraldi PG, Carrion MD, Cruz-Lopez O, Cara CL, Balzarini J, Hamel E, Canella A, Fabbri E, Gambari R, Basso G, Viola G. Bioorg. Med. Chem. Let. 2009; 19:2022. [PubMed: 19250822]

3. Dore JC, Viel C. J. Pharm. Belg. 1974; 29:341. [PubMed: 4421588]

4. Dauksas V, Gaidelis P, Udrenaite E, Petrauskas O, Brukstus A. Khim. Farm. Zh. 1985; 19:1069.

5. Kim YH, Kim J, Park H, Kim HP. Biol. Pharm. Bull. 2007; 30:1450. [PubMed: 17666802]

6. Baell Jonathan B, Gable Robert W, Harvey Andrew J, Toovey N, Herzog T, Hansel W, Wulff H. J. Med. Chem. 2004; 47:2326. [PubMed: 15084131]

7. Avila HP, Smania EdFA, Delle Monache F, Smania A Jr. Bioorg.Med. Chem. 2008; 16:9790. [PubMed: 18951808]

8. Li R, Kenyon GL, Cohen FE, Chen X, Gong B, Dominguez JN, Davidson E, Kurzban G, Miller RE, Nuzum EO, Rosenthal PJ, McKerrow JH. J. Med. Chem. 1995; 38:5031. [PubMed: 8544179]

9. Nielsen SF, Christensen SB, Cruciani G, Kharazmi A, Liljefors T. J. Med. Chem. 1998; 41:4819. [PubMed: 9822551]

10. Aponte JC, Verastegui M, Malaga E, Zimic M, Quiliano M, Vaisberg AJ, Gilman RH, Hammond GB. J. Med. Chem. 2008; 51:6230. [PubMed: 18798609]

11. Matsuda H, Morikawa T, Ando S, Toguchida I, Yoshikawa M. Bioorg. Med. Chem. 2003; 11:1995. [PubMed: 12670650] 
12. Lawrence Nicholas J, McGown Alan T. Curr. Pharm. Des. 2005; 11:1679. [PubMed: 15892668]

13. Zhou J, Geng G, Batist G, Wu JH. Bioorg. Med. Chem. Let. 2009; 19:1183. [PubMed: 19138519]

14. Modzelewska A, Pettit C, Achanta G, Davidson NE, Huang P, Khan SR. Bioorg. Med. Chem. 2006; 14:3491. [PubMed: 16434201]

15. Kagechika H, Shudo K. J. Med. Chem. 2005; 48:5875. [PubMed: 16161990]

16. Asato AE, Peng A, Hossain MZ, Mirzadegan T, Bertram JS. J. Med. Chem. 1993; 36:3137. [PubMed: 8230100]

17. Gopaluni S, Perzova R, Abbott L, Farah R, Shrimpton A, Hutchison R, Poiesz BJ. Am. J. Hematol. 2008; 83:744. [PubMed: 18615708]

18. Kagechika H, Kawachi E, Hashimoto Y, Shudo K. J. Med. Chem. 1989; 32:834. [PubMed: 2704028]

19. Ju J, Hong J, Zhou J-n, Pan Z, Bose M, Liao J, Yang G-y, Liu YY, Hou Z, Lin Y, Ma J, Shih WJ, Carothers AM, Yang CS. Cancer Res. 2005; 65:10623. [PubMed: 16288056]

20. Paul S, De Castro AJ, Lee HJ, Smolarek AK, So JY, Simi B, Wang CX, Zhou R, Rimando AM, Suh N. Carcinogenesis. 2010; 31:1272. [PubMed: 20061362]

21. Paul S, Mizuno CS, Lee HJ, Zheng X, Chajkowisk S, Rimoldi JM, Conney A, Suh N, Rimando AM. Eur. J. Med. Chem. 2010; 45:3702. [PubMed: 20627379]

22. Paul S, Rimando AM, Lee HJ, Ji Y, Reddy BS, Suh N. Cancer Prev. Res. 2009; 2:650.

23. Faul MM, Ratz AM, Sullivan KA, Trankle WG, Winneroski LL. J. Org. Chem. 2001; 66:5772. [PubMed: 11511251]

24. Roberti M, Pizzirani D, Simoni D, Rondanin R, Baruchello R, Bonora C, Buscemi F, Grimaudo S, Tolomeo M. J. Med. Chem. 2003; 46:3546. [PubMed: 12877593]

25. Johnston BD, Czyzewska E, Oehlschlager AC. J. Org. Chem. 1987; 52:3693. 


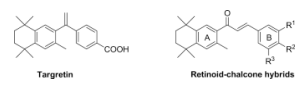

Figure 1.

Chemical structure of targretin and retinoid-chalcone hybrids. 


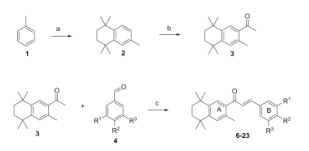

Scheme 1.

Synthesis of retinoid-chalcone hybrids. Reagents and conditions: (a) 2,5-dichloro-2,5dimethylhexane, $\mathrm{AlCl}_{3}$, DCM, 2h, rt; (b) Acetyl chloride, $\mathrm{AlCl}_{3}, \mathrm{DCM}, 2 \mathrm{~h}$, reflux; (c) $\mathrm{NaOH}, \mathrm{EtOH}, \mathrm{rt}, 15 \mathrm{hr}$. 
Table 1

Anticancer activity of retinoid-chalcone derivatives against HT-29 cells.

\begin{tabular}{|c|c|c|c|c|}
\hline \multicolumn{5}{|c|}{ otho pain } \\
\hline Compound & $\mathbf{R}^{1}$ & $\mathbf{R}^{2}$ & $\mathbf{R}^{3}$ & $\mathrm{IC}_{50} \pm \mathrm{SD}(\mu \mathrm{M})^{*}$ \\
\hline 5 & & & & $3.70 \pm 0.21$ \\
\hline 6 & $\mathrm{H}$ & $\mathrm{CN}$ & $\mathrm{H}$ & $1.94 \pm 0.57$ \\
\hline 7 & $\mathrm{H}$ & $\mathrm{H}$ & $\mathrm{H}$ & $2.86 \pm 1.09$ \\
\hline 8 & $\mathrm{CN}$ & $\mathrm{H}$ & $\mathrm{H}$ & $0.66 \pm 0.25$ \\
\hline 9 & $\mathrm{H}$ & $\mathrm{OCH}_{3}$ & $\mathrm{H}$ & $4.13 \pm 1.06$ \\
\hline 10 & $\mathrm{H}$ & $\mathrm{CF}_{3}$ & $\mathrm{H}$ & $2.83 \pm 0.35$ \\
\hline 11 & $\mathrm{H}$ & $\mathrm{Br}$ & $\mathrm{H}$ & $5.02 \pm 0.17$ \\
\hline 12 & $\mathrm{H}$ & $\mathrm{NO}_{2}$ & $\mathrm{H}$ & $1.46 \pm 0.22$ \\
\hline 13 & $\mathrm{H}$ & $\mathrm{N}\left(\mathrm{CH}_{3}\right)_{2}$ & $\mathrm{H}$ & $6.59 \pm 0.33$ \\
\hline 14 & $\mathrm{OH}$ & $\mathrm{H}$ & $\mathrm{H}$ & $2.66 \pm 0.43$ \\
\hline 15 & $\mathrm{NH}_{2}$ & $\mathrm{H}$ & $\mathrm{H}$ & $6.99 \pm 1.22$ \\
\hline 16 & $\mathrm{H}$ & $\mathrm{OCH}_{2} \mathrm{CHC}\left(\mathrm{CH}_{3}\right)_{2}$ & $\mathrm{H}$ & $13.33 \pm 1.40$ \\
\hline 17 & $\mathrm{OCH}_{2} \mathrm{CHC}\left(\mathrm{CH}_{3}\right)_{2}$ & $\mathrm{H}$ & $\mathrm{H}$ & $3.73 \pm 0.07$ \\
\hline 18 & $\mathrm{OCH}_{3}$ & $\mathrm{H}$ & $\mathrm{OCH}_{3}$ & $1.54 \pm 0.16$ \\
\hline 19 & $\mathrm{OCH}_{3}$ & $\mathrm{OCH}_{3}$ & $\mathrm{H}$ & $8.32 \pm 1.59$ \\
\hline 20 & $\mathrm{NO}_{2}$ & $\mathrm{H}$ & $\mathrm{H}$ & $1.45 \pm 0.04$ \\
\hline 21 & $\mathrm{H}$ & $5-1 \mathrm{H}$ tetrazole & $\mathrm{H}$ & $23.52 \pm 1.00$ \\
\hline 22 & $\mathrm{Cl}$ & $\mathrm{Cl}$ & $\mathrm{H}$ & $8.12 \pm 0.27$ \\
\hline 23 & $\mathrm{OH}$ & $\mathrm{OCH}_{3}$ & $\mathrm{H}$ & $1.59 \pm 0.14$ \\
\hline
\end{tabular}

The experiments were performed twice and the average values were obtained from two independent experiments 